\title{
Prognosis of fungal infection of central nervous system in HIV-infected patients: a retrospective study of 77 patients in Ukraine
}

\author{
Kateryna Y. Lytvyn ${ }^{1}$, Liudmyla R. Shostakovych-Koretskaya ${ }^{1}$, Anna A. Doroshenko ${ }^{1}$, Tatiana I. Andreeva ${ }^{2,3}$ \\ ${ }^{1}$ Dnipropetrovsk Medical Academy of Health Ministry of Ukraine, Ukraine \\ ${ }^{2}$ Alcohol and Drug Information Centre (ADIC), Ukraine \\ ${ }^{3}$ School of Public Health, Babeș-Bolyai University, Cluj-Napoca, Romania
}

\begin{abstract}
Introduction: We aimed to describe the epidemiological, clinical, laboratory characteristics, and outcomes of central nervous system (CNS) mycosis in patients with human immunodeficiency virus (HIV) and to determine characteristics associated with a higher risk of death. Retrospective data from 77 case histories of HIV-infected patients with neurological symptoms caused by various fungi including Candida and Cryptococcus in Dnipro, Ukraine, were analysed as a case-control study with 40 deceased individuals considered as cases and 37 patients with favourable outcome (survivors) considered as controls.

Material and methods: Fungi in cerebrospinal fluid (CSF) were detected with traditional culture methods. Multivariate analysis used (1) binary logistic regression with survivor/dead as a dependent variable and (2) a classification and regression tree (CRT method).

Results: A combination of fungal infection with other infections of CNS (dual and triple coinfection) was diagnosed in most cases ( $n=53,68.8 \%$ ), while the proportion of co-infection was somewhat lower among survivors (59.5\%). Clinical manifestations were non-specific. Risk of death was higher among those with tuberculosis ( $\mathrm{AOR}=2.7,95 \% \mathrm{CI}$ : 1.0-7.5) and lower among those infected with Epstein-Barr virus (EBV) ( $\mathrm{AOR}=0.3,95 \%$ CI: 0.1-1.0) and among patients on ART ( $\mathrm{AOR}=0.2$, 95\% CI: 0.1-0.8). Risk of death significantly decreased over time. The classification tree shows that among HIV-mycosis neurological patients not on ART with tuberculosis, the risk of death constituted $75 \%$, while among patients on ART with EBV-infection, all patients survived.

Conclusions: Opportunistic mycoses remain an important clinical challenge among immuno-compromised patients especially those who were diagnosed with HIV late, failed to get antiretroviral therapy, and developed tuberculosis.
\end{abstract}

HIV AIDS Rev 2019; 18, 2: 92-99

DOI: https://doi.org/10.5114/hivar.2019.86373

Key words: opportunistic mycoses, central nervous system diseases, fatal outcome, coinfection, candidiasis, HIV, antiretroviral therapy, opportunistic infections.

Address for correspondence: Tatiana I. Andreeva, Alcohol and Drug Information Centre (ADIC), Ukraine, phone: 380504165200 , e-mail: tatianandreeva@gmail.com
Article history:

Received: 25.09.2018

Received in revised form: 26.11.2018

Accepted: 15.04.2019

Available online: 11.06.2019
International Journal of HIV-Related Problems

HIV \& AIDS

R e vi e w 


\section{Introduction}

Opportunistic infections are among the major problems faced by human immunodeficiency virus (HIV)-infected patients and a major cause of death [1], especially in countries with high HIV incidence and reduced access to antiretroviral therapy [2].

Opportunistic infections of the central nervous system (CNS) are common complications of advanced immunodeficiency $[3,4]$ in individuals with human immunodeficiency virus type 1 (HIV-1) infection. Neurological manifestations are seen in $10 \%$ to $20 \%$ of symptomatic HIV-1 infection, while prompt diagnosis and treatment of these disorders are critical [5]. Additionally, in the era of highly active antiretroviral therapy (HAART), neurological manifestations of HIV have changed in presentation and epidemiology [6], and the aetiological composition of $\mathrm{HIV}$-associated neurological diseases varies by region of the world [1,7-9].

Fungal infections including Cryptococcus, Candida, Histoplasma, and Aspergillus remain a challenge among other opportunistic infections [10] due to the high rate of related morbidity and mortality $[11,12]$. Studies based on autopsies of immunocompromised patients show that fungal infection can be found in $9 \%$ of autopsy cases with the brain being the most common single organ affected by fungi [13]. Species of Candida and Aspergillus remain the most common agents of invasive fungal infections [14]. The increased spread of candidal infection might be due to the emergence of resistant species and the acquisition of resistance in previously susceptible species [15]. The CNS mycosis may be disseminated (cryptococcosis, coccidioidomycosis, etc.), focal (aspergillosis, zygomycosis, etc.), or multifocal (candidiasis) [11].

Fungal encephalitis lesions were characterised by deep damage and poor regeneration of neurons, which can be the cause of severe clinical manifestations and high mortality [16]. Clinical manifestations of fungal infection of the CNS have great variability which include abscesses, meningitis or meningoencephalitis, focal masses, ischaemic (commonly) or haemorrhagic (uncommonly) stroke/vasculitis, immune reconstitution inflammatory syndrome (IRIS), progressive myelopathic syndromes, and arachnoiditis [17].

Along with studies pointing to the high risk of death among patients with brain damage caused by various fungi [10], little is known about other predictors of survival among these patients. Clinical and laboratory characteristics and their discrepancies between survivors and fatal cases have also not been thoroughly studied.

We review socio-demographic, clinical, and laboratory characteristics of HIV patients with fungal infection of CNS with the aim to identify those able to predict the outcome. The study is conducted in Ukraine, a country with an HIV epidemic characterised by high incidence and prevalence [18]. This epidemic was initially propelled by injection drug use, but heterosexual transmission has become a major driver of new infections [19].

\section{Material and methods}

This analysis was based on the retrospective data from 77 cases of HIV-infected patients with neurological symptoms caused by fungi revealed in cerebrospinal fluid (CSF) culture between 2010 and 2016 in Dnipro city and Dnipropetrovsk regional clinical centres for HIV/AIDS prevention and control. Among these, 40 cases were with fatal outcome (deceased individuals) and 37 cases with favourable outcome (survivors).

All cases of fungal infection in CSF were diagnosed with traditional culture methods. For the isolation of colonies, the cerebrospinal fluid was centrifuged and $0.1 \mathrm{ml}$ of it was inoculated on Sabouraud dextrose agar. The plates were incubated at $37^{\circ} \mathrm{C}$ for 2-3 days. Several colonies suspected as Candida were inoculated to a liquid medium to identify filamentous growth specific for Candida. To determine the number of yeast cells in $1 \mathrm{ml}$ the counted number of colonies on the plate was multiplied by 10 . Microscopy of Gram-stained thin smears of the matter from isolated colonies was aimed at detection of budding yeast-like cells and pseudohyphae showing regular points of constriction. Gram-stained thin smear preparations of cerebrospinal fluid before microscopy were dried and fixed with methyl alcohol. Identification of Candida species was based on the biochemical properties of the fungi. Identification of other concomitant CNS infectious agents, in addition to fungi, in CSF and/ or autopsy material was carried out using polymerase chain reaction and culture methods.

The analysis is limited to those characteristics which were routinely collected and registered in medical records. These included patient demographics and clinical characteristics, comorbidities, medications, and HIV-specific information such as CD4 and viral load (where available). No additional measurements were taken for the study. The Bioethics Commission of Dnipropetrovsk Medical Academy (Ukraine) reviewed and approved the study.

Descriptive statistics of categorical and metric variables were used to compare two groups of patients. In bivariate analysis, variables associated with disease outcome were revealed. Multivariate analysis used binary logistic regression with survivor/dead as a dependent variable and classification tree with CRT method. All statistical analyses were performed using SPSS version 21.

\section{Results}

All 77 patients with fungal and potentially Candida infection of CNS were adults with mean age 38.3 years (ranging from 19 to 59 years; standard deviation $[S D]=7.5$ ). Most of the patients were aged 35-44 years. Males constituted the majority ( $n=48,62.3 \%$ ), with $67.5 \%$ being males among those who died.

Candida was biochemically confirmed for 37 patients; other fungal agents were considered as various yeasts. A combination of fungal infection with other infections of CNS (dual and triple coinfection) was diagnosed in most 
cases $(n=53,68.8 \%)$ while the proportion of co-infection was somewhat lower among survivors (59.5\%) than among the deceased patients $(77.5 \%)$ (Table 1$)$.

Cerebral tuberculosis was identified in 31 patients $(58.5 \%$ of those with coinfection), 21 (67.7\%) of them died in hospital. Epstein-Barr virus (EBV) DNA was detected in the CSF of 15 (28.3\%) individuals; progressive multifocal leukoencephalopathy (PML) caused by John Cunningham virus (JCV) was diagnosed in $6(11.3 \%)$ patients, Toxoplasma and Cryptococcus were accountable for four (7.5\%) cases each, and herpes simplex virus (HSV) and bacterial meningitis were present in three $(5.7 \%)$ cases each. Two patients (3.8\%) with fungal infection were also diagnosed with a stroke.

The most common clinical manifestations in patients with fungal monoinfection were a headache (23 of 24 patients - 95.8\%), coordination disorders: vertigo, gait unsteadiness, and coordination test failures (19 persons - 79.3\%); positive meningeal symptoms (mainly neck stiffness) were observed in $10(41.7 \%)$ patients; impaired consciousness occurred in three $(12.5 \%)$ cases; cognitive disorders in $4(16.7 \%)$ cases; visual disturbances were detected in six $(25.0 \%)$ patients; deficiency of cranial nerves in eight (33.3\%); convulsions in three $(12.5 \%)$; dysarthria in three $(12.5 \%)$, tremor of the tongue in one patient (4.2\%); and eyelid tremor in one patient as well (4.2\%).

Among those for whom the route of HIV transmission was known, $66.7 \%$ were people who injected drugs; this percentage was higher $(74.2 \%)$ among the survivors. For half of the deceased patients, the route of transmission was unknown because their HIV-infection was diagnosed just before the death and their physical state did not allow undertaking a detailed interview.

The time span between the detection of HIV and the development of CNS fungal infection averaged 3.7 ( $\mathrm{SD}=4.5$ ) years ranging from 0 to 17 years with median time constituting one year and no significant difference found between the groups of those who died and who survived (Table 1). In almost half of the patients who died (45.0\%) and more than a third of the surviving patients (35.1\%), HIV-infection was diagnosed late, within the same year or simultaneously with the identification of CNS manifestations. Therefore, only some patients had HIV viral load measurements, and ART coverage before the appearance of neurological symptoms was rather low $(n=20,26.0 \%): 15.0 \%$ of those who died and $37.8 \%$ of survivors.

HIV viral load measurements were available for $23 \mathrm{pa}$ tients (29.9\%) (Table 1). Most of these patients $(n=20$, 98.2\%) had HIV viral loads above 50 copies $/ \mathrm{ml}$. All deceased patients had viral load counts $\geq 50$ copies/ml. Median HIV viral load was 135,537 copies/ml (range 40-1,926,802). The median viral load was higher in deceased patients $(185,971$ copies/ml; range 5309-478,504) than in survivors.

Most patients $(n=48,62.3 \%)$ had an absolute CD4 count $<50$ cells $/ \mu$ l, which corresponded to severe immunosuppression. Only a few patients $(n=5,6.5 \%)$ had an absolute CD 4 count above 200 cells/ $\mu$ l. Median CD4 cell count was 50 cells/ $\mu$ ( range 1-461) in the whole group and among the surviving patients, and 34 cells/ $\mu$ (range 1-216) among the patients who died.

Comparison of immunologic and viral load indicators between the groups of patients with fungal monoinfection and patients with coinfection (Table 2 ) demonstrated no significant difference between the groups $(p>0.05)$.

Almost half of the patients $(n=38,49.4 \%)$ had pleocytosis: increased CSF white blood cells (WBCs) were found in $50.0 \%$ of deceased patients and $48.6 \%$ of survivor-patients (Table 1). Median CSF WBCs was 14.0 per $\mathrm{mm}^{3}$ (range $0-853$ ). Deceased patients had higher median CSF WBCs 21.0 per $\mathrm{mm}^{3}$ (range $0-853$ ). Parameters of the cerebrospinal fluid in patients with Candida monoinfection (Table 1) did not show differences between those who died and those who survived $(p>0.05)$. Increased CSF WBCs were found in about one-third of patients with monoinfection: in 33.3\% of patients who died and in $26.7 \%$ of survivors. In the case of coinfection, these proportions were $54.8 \%$ and $63.6 \%$, respectively. However, comparison of CSF WBCs between all patients and patients with fungal monoinfection shows that pleocytosis counts were much higher among those with coinfection than among patients with fungal monoinfection.

In the group of patients who survived, the maximum number of WBCs in the CSF was 148.0 per $\mathrm{mm}^{3}$ in patients with monoinfection and 496.0 per $\mathrm{mm}^{3}$ in patients with coinfection, and mean CSF WBC, respectively, was 26.3 (SD - 44.4) cells $/ \mathrm{mm}^{3}$ and 45.5 (SD - 105.6) cells $/ \mathrm{mm}^{3}$. Among the fatal cases, these rates were correspondingly: 92.0 cells $/ \mathrm{mm}^{3}$ and mean CSF WBCs - 17.4 (SD - 29.5)/ $/ \mathrm{mm}^{3}$ in patients with monoinfection and 853.0 cells $/ \mathrm{mm}^{3}$ and mean CSF WBCs 101.2 (SD - 177.0) cells $/ \mathrm{mm}^{3}$ in the case of coinfection.

Mean CSF protein concentration was 0.3 (SD - 0.2) g/l and was not different in survivors and deceased patients. The CSF glucose level ranged between 1.2 and $4.8 \mathrm{mmol} / \mathrm{l}$ and was normal in most patients and did not differ much between those who died and those who survived $(2.4$ [SD $=0.8$ ] $\mathrm{mmol} / \mathrm{l}$ vs. 2.7 [SD = 1.2] $\mathrm{mmol} / \mathrm{l}$ ).

Multivariate analysis using binary logistic regression model with alive/dead dependent variable (see Table 3 ) revealed that the risk of death was higher among those with tuberculosis $(\mathrm{AOR}=2.7,95 \% \mathrm{CI}: 1.0-7.5)$ and lower among those infected with Epstein-Barr virus $(\mathrm{AOR}=0.3,95 \% \mathrm{CI}$ : 0.1-1.0) and patients on ART (AOR = 0.2, 95\% CI: 0.1-0.8).

Risk of death significantly decreased over time; however, because this association did not confound those described above, and the year of neurological diagnosis was not entered in the final regression model.

A classification tree built using the CRT method (see Figure 1) allowed for $71.4 \%$ accuracy of prediction and provided estimated risks for all the combinations of ART, tuberculosis, and EBV. As the decision tree shows, among HIV-mycosis neurological patients not on ART with tuberculosis, the risk of death constituted $75 \%$, while only $12.5 \%$ of patients not on ART with EBV-infection died. Among HIV-mycosis neurological patients on ART, if tuberculosis was also diagnosed, the risk of death was $50 \%$ while among patients on ART with EBV-infection, all patients survived. 
Table 1. Characteristics of 77 patients with HIV and fungal infection of central nervous system in Dnipropetrovsk region, Ukraine, 2010-2016

\begin{tabular}{|c|c|c|c|}
\hline Characteristic & Total & Deceased & Survivors \\
\hline Patients, $n(\%)$ & $77(100)$ & $40(51.9)$ & $37(48.1)$ \\
\hline Age, mean (SD), years & $38.3(7.5)$ & $37.7(7.6)$ & $39.0(7.5)$ \\
\hline Age, range, years & $19-59$ & $25-59$ & $19-56$ \\
\hline Male gender, $n(\%)$ & $48(62.3)$ & $27(67.5)$ & $21(56.8)$ \\
\hline \multicolumn{4}{|c|}{ HIV transmission, $n$ (\% among those with known mechanism) } \\
\hline Parenteral (PWID) & $34(66.7)$ & $11(55.0)$ & $23(74.2)$ \\
\hline Sexual & $17(33.3)$ & $9(45.0)$ & $8(25.8)$ \\
\hline Total, $n$ & $51(100)$ & $20(100)$ & $31(100)$ \\
\hline Unknown transmission mechanism, $n(\%)$ & $26(33.7)$ & $20(50.0)$ & $6(16.2)$ \\
\hline \multicolumn{4}{|c|}{ Duration of the period from the diagnostics of HIV-infection to the development of neurological symptoms, number of patients, $n$ (\%) } \\
\hline$>9$ years & $9(11.7)$ & $6(15.0)$ & $3(8.1)$ \\
\hline $5-9$ years & $19(24.7)$ & $7(17.5)$ & $12(32.4)$ \\
\hline $1-4$ years & $17(22.1)$ & $9(22.5)$ & $9(24.3)$ \\
\hline$<1$ year & $32(41.5)$ & $18(45.0)$ & $13(35.1)$ \\
\hline Mean duration (SD), years & $3.7(4.5)$ & $3.4(4.6)$ & $4.0(3.5)$ \\
\hline Median duration (range), years & $1.0(0-17)$ & $1.0(0-17)$ & $3.5(0-17)$ \\
\hline \multicolumn{4}{|c|}{ Immunologic status: CD4 cell count, $n(\%)$, cells/ $\mu$ interval (1) } \\
\hline$<200$ & $72(93.5)$ & $39(97.5)$ & $33(89.2)$ \\
\hline$\geq 200$ & $5(6.5)$ & $1(2.5)$ & $4(10.8)$ \\
\hline \multicolumn{4}{|l|}{ CD4 cell count, $n$ (\%), cells/ $\mu$ l interval (2) } \\
\hline $0-50$ & $48(62.3)$ & $27(67.5)$ & $21(56.8)$ \\
\hline $51-100$ & $11(14.3)$ & $6(15.0)$ & $5(13.5)$ \\
\hline $101-200$ & $13(16.9)$ & $6(15.0)$ & $7(18.9)$ \\
\hline $201-500$ & $5(6.5)$ & $1(2.5)$ & $4(10.8)$ \\
\hline Mean CD4 cells/ $\mu \mathrm{l}(\mathrm{SD})$ & $72.9(94.0)$ & $51.3(52.4)$ & $96.2(120.9)$ \\
\hline Median CD4 cells/ $\mu$ l (range) & $50(1-461)$ & $34(1-216)$ & $50(4-461)$ \\
\hline \multicolumn{4}{|l|}{ HIV viral load, interval, $n$ (\%) copies/ml } \\
\hline$<50$ & $3(13.0)$ & $0(0.0)$ & $3(8.1)$ \\
\hline$\geq 50$ & $20(87.0)$ & $11(100)$ & 9 (91.9) \\
\hline Total, $n$ (\%) & 23 & 11 & 12 \\
\hline Mean HIV viral load copies/ml (SD) & $255,032(438,584)$ & $192,796(141,842)$ & $312,082(599,164)$ \\
\hline Median HIV viral load copies/ml (range) & $135,537(40-1,926,802)$ & $185,971(5,309-478,504)$ & $70,362(40-1,926,802)$ \\
\hline Median HIV viral load copies/ml (range) log10 & $5.1(1.6-6.0)$ & $5.3(3.7-5.7)$ & $4.8(1.6-6.1)$ \\
\hline Receiving ART, $n$ (\%) & $20(26.0)$ & $6(15.0)$ & $14(37.8)$ \\
\hline Fungal monoinfection, $n(\%)$ & $24(31.2)$ & $9(22.5)$ & $15(40.5)$ \\
\hline Coinfection with other pathogens, $n(\%)$ & $53(68.8)$ & $31(77.5)$ & $22(59.5)$ \\
\hline \multicolumn{4}{|c|}{ Structure of coinfection with other pathogens in central nervous system } \\
\hline MBT & $31(58.5)$ & $21(67.7)$ & $10(45.5)$ \\
\hline EBV & $15(28.3)$ & $4(12.9)$ & $11(50.0)$ \\
\hline Bacterial infection (purulent meningitis) & $3(5.7)$ & $3(9.6)$ & $0(0.0)$ \\
\hline Toxoplasma & $4(7.5)$ & $1(3.2)$ & $3(13.6)$ \\
\hline Cryptococcus & $4(7.5)$ & $3(9.6)$ & $1(4.5)$ \\
\hline CMV & $1(1.9)$ & $1(3.2)$ & $0(0.0)$ \\
\hline JCV (PML) & $6(11.3)$ & 6 (19.4) & $0(0.0)$ \\
\hline HSV & $3(5.7)$ & $3(9.6)$ & $0(0.0)$ \\
\hline
\end{tabular}


Table 1. Cont.

\begin{tabular}{|c|c|c|c|}
\hline Characteristic & Total & Deceased & Survivors \\
\hline \multicolumn{4}{|l|}{ Characteristic of CSF } \\
\hline \multicolumn{4}{|c|}{ Presence of pleocytosis (increase of CSF WBCs), $n(\%)$} \\
\hline Among all & $38 / 77(49.4)$ & $20 / 40(50.0)$ & $18 / 37(48.6)$ \\
\hline Among patients with fungal monoinfection & $7 / 24(29.2)$ & $3 / 9(33.3)$ & $4 / 15(26.7)$ \\
\hline Among patients with fungal coinfection & $31 / 53(58.5)$ & $17 / 31(54.8)$ & $14 / 22(63.6)$ \\
\hline \multicolumn{4}{|l|}{ Mean CSF WBCs/mm³ (SD) } \\
\hline Among all & $67.6(136.5)$ & $89.1(164.5)$ & $42.7(90.9)$ \\
\hline Among patients with fungal monoinfection & $22.7(38.4)$ & $17.4(29.5)$ & $26.3(44.4)$ \\
\hline Among patients with fungal coinfection & $78.5(152.7)$ & $101.2(177.0)$ & $45.5(105.6)$ \\
\hline \multicolumn{4}{|l|}{ Median CSF WBCs/mm³ (range) } \\
\hline Among all & $14.0(0-853.0)$ & $21.0(0-853.0)$ & $10.5(0-96.0)$ \\
\hline Among patients with fungal monoinfection & $3.5(0.0-148.0)$ & $5.0(1.0-92.0)$ & $3.0(0.0-148.0)$ \\
\hline Among patients with fungal coinfection & $14.0(0-853.0)$ & $21.0(0-853.0)$ & $14.0(0.0-496.0)$ \\
\hline
\end{tabular}

PWID - people who inject drugs, MBT - Mycobacterium tuberculosis, EBV - Epstein-Barr virus, CMV - Cytomegalovirus, JCV - John Cunningham virus, $P M L$ - progressive multifocal leukoencephalopathy, HSV - herpes simplex virus, CSF - cerebrospinal fluid, WBCS - white blood cells

Table 2. Immunologic and viral load status of patients with fungal mono-infection and patients with fungal coinfection

\begin{tabular}{|c|c|c|}
\hline Characteristic & Monoinfection & Coinfection \\
\hline CD4 cell count, $n$ & 24 & 53 \\
\hline \multicolumn{3}{|l|}{ CD4 cell count interval, $n$ (\%), cells/ $\mu$ l } \\
\hline $0-50$ & $16(66.6)$ & $33(62.3)$ \\
\hline $51-100$ & $4(16.7)$ & $7(13.2)$ \\
\hline $101-200$ & $4(16.7)$ & $8(15.1)$ \\
\hline $201-500$ & $0(0.0)$ & $5(9.4)$ \\
\hline Mean cells/ $\mu \mathrm{l}(\mathrm{SD})$ & $54.0(51.1)$ & $81.4(107.4)$ \\
\hline Median cells/ $\mu$ l (range) & $42.0(4.0-178.0)$ & $50.0(1.0-461.0)$ \\
\hline HIV viral load counts, $n$ & 7 & 16 \\
\hline \multicolumn{3}{|l|}{ HIV viral load, interval, $n$ (\%) copies/ml } \\
\hline$<50$ & $0(0.0)$ & $2(12.5)$ \\
\hline$\geq 50$ & $7(100.0)$ & $14(81.3)$ \\
\hline Mean HIV viral load copies/ml (SD) & $365,822(698,629)$ & $206,562(280,465)$ \\
\hline Median HIV viral load copies/ml (range) & $74,509(11,458-1,926,802)$ & $155,384(40-1,146,096)$ \\
\hline
\end{tabular}

Table 3. Binary logistic regression of the risk of death among HIV patients with neurological complications caused by yeasts

\begin{tabular}{|c|c|c|c|c|c|c|}
\hline \multirow{2}{*}{ Independent variable } & \multirow{2}{*}{ Values } & \multirow{2}{*}{ Number of patients } & \multicolumn{2}{|c|}{ Deaths } & \multirow{2}{*}{ AOR $(95 \% \mathrm{Cl})$} & \multirow{2}{*}{$p$-value } \\
\hline & & & $n$ & $\%$ & & \\
\hline \multirow{2}{*}{ ART } & No & 56 & 34 & 61 & 1.0 (Ref) & \multirow[t]{2}{*}{0.016} \\
\hline & Yes & 21 & 6 & 29 & $0.2(0.1-0.8)$ & \\
\hline \multirow{2}{*}{ TB } & No & 46 & 19 & 41 & 1.0 (Ref) & \multirow[t]{2}{*}{0.060} \\
\hline & Yes & 31 & 21 & 68 & $2.7(1.0-7.5)$ & \\
\hline \multirow{2}{*}{ EBV } & No & 62 & 36 & 58 & 1.0 (Ref) & \multirow[t]{2}{*}{0.046} \\
\hline & Yes & 15 & 4 & 27 & $0.3(0.1-1.0)$ & \\
\hline
\end{tabular}

$A R T$ - antiretroviral therapy, TB - tuberculosis, EBV - Epstein-Barr virus 


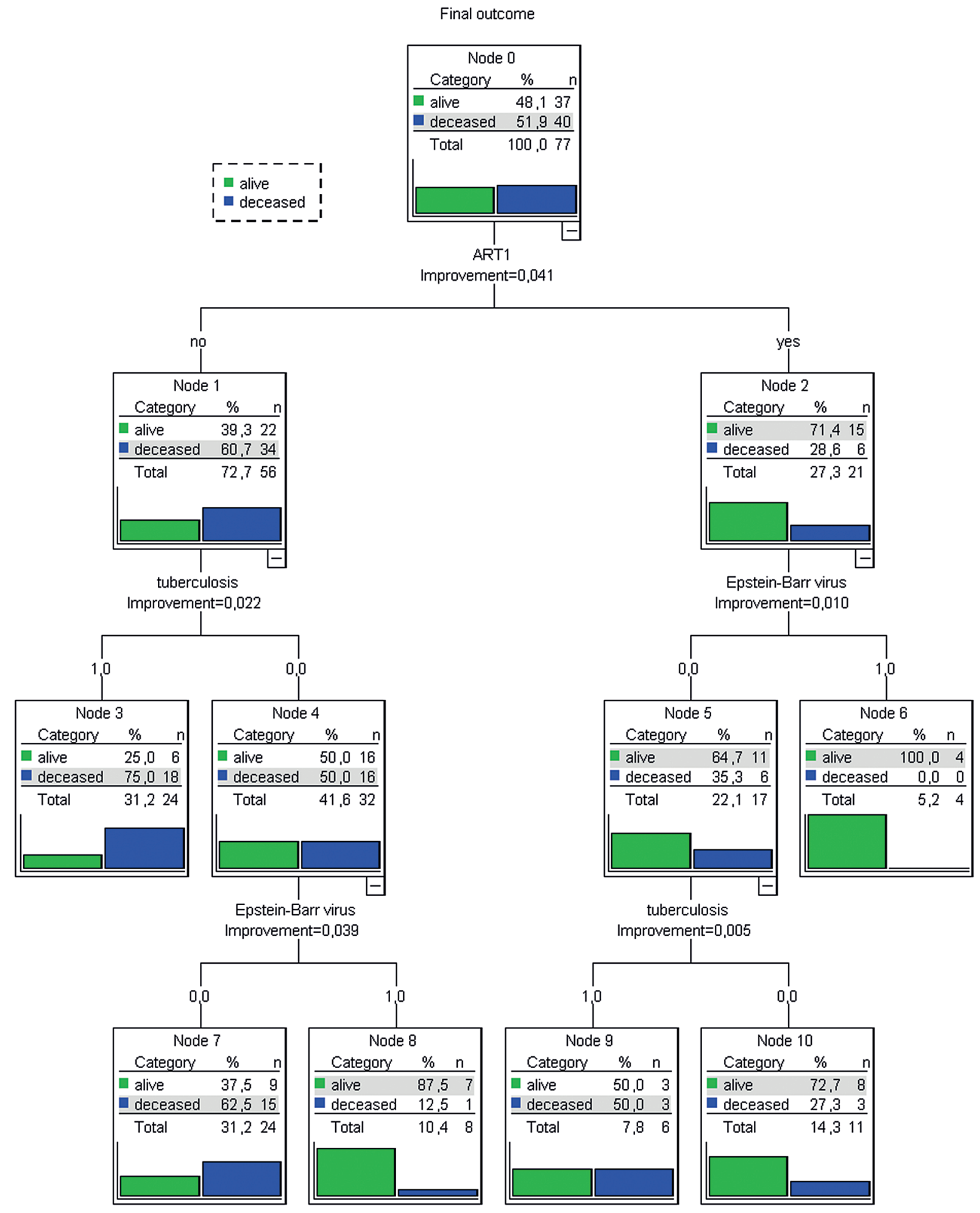

Figure 1. Classification tree of final outcomes of neurologic complications caused by fungal infections among HIV patients, CRT method, Dnipropetrovsk HIV hospital 


\section{Discussion}

The conducted analysis of 77 HIV patients with neurological complications caused by various fungi revealed that all the cases developed in patients with expressed immunosuppression, which is consistent with other studies [10]. The emergence of invasive fungal infections might be precipitated by various factors. Late diagnostics and no prophylaxis to prevent invasive candidiasis [20] along with absence of ARV treatment was quite widespread among the considered patients. Many patients with HIV in Ukraine were infected due to use of home-made opiate drugs [19] injected with used syringes and needles. An additional risk factor emphasised in the literature [20] may be related to the use of central venous catheters while providing intensive care. If those catheters are not removed in a timely manner, the risk of invasive infections might increase.

In most cases, invasive fungal infections of CNS were diagnosed in combination with other infections, which complicated an objective assessment of clinical and laboratory characteristics. Additionally, laboratorial distinguishing between various fungi remains challenging [21-23].

The considered cases of fungal infections of the central nervous system were marked with high case fatality (52\%). The risk of death was higher among patients with tuberculosis coinfection whereas getting antiretroviral therapy and being infected with Epstein-Barr virus were associated with lower case fatality. Findings related to ART and tuberculosis are consistent with published research because antiretroviral therapy has a known beneficial effect on the outcomes of HIV-associated neurological complications [24, 25]. Tuberculosis remains a risk factor of death among HIV patients, especially in poorer countries [26-28].

Epstein-Barr virus was mentioned among other coinfections found in cerebrospinal fluid in association with increased mortality [29]. While this contradicts our findings, no interaction of EBV and yeasts was assessed in the mentioned study, and although both agents are mentioned in several studies devoted to HIV-related clinical manifestations, none of them considers the combined impact of EBV and fungi. We hypothesise that the activation of cellular immunity as a component of EBV infection might impact the response to agents of opportunistic infections. T-cells bear functional defects [30], and natural killers decrease in all stages of HIV infection [31] while the Epstein-Barr virus infection is characterised by elevated cytotoxic/suppressor (CD8) T cells, natural killer (CD16) cells, and helper (CD4) T cells [32, 33], which are found both at the onset of the infection and over time [34]. The T-cell populations activated in EBV can be effective in attacking various fungi: CD8+ mediates the antifungal activity against Candida albicans [35]; with regard to Cryptococcus neoformans, the fungistatic role of CD4+, CD8+, and $\mathrm{CD} 16 / 56+$ lymphocytes was shown in vitro and in vivo $[36,37]$, and CD8+ T cells were shown to independently mediate an inflammatory response [38].

Clinical manifestations were found to be non-specific and comprising fever, headache, neck stiffness, and mental status impairment similarly to those reported by other authors [14] along with others which include vomiting, visual alterations, paralysis of cranial nerves, and confusion [39]. This makes clinical diagnosis challenging, especially because fungal infections generally have a subacute onset [40] and present similarly to various bacterial infections [41]. In HIV patients, headache and fever can be unique symptoms, and only CD4 count can help with diagnosis [42].

Our finding that patients with fungal infections had pleocytosis counts much higher in cases of coinfection suggests that the cause of pleocytosis may be due to other factors, first of all, mycobacterial infections and causative agents of purulent meningitis. However, pleocytosis and hypoglycorrhachia in fungal meningitis might be indistinguishable from that seen in tuberculous meningitis [43].

While most of the patients were middle-aged men with the majority having experience of injection drug use, these characteristics are not associated with the risk of neurological complications or increased risk of death, they are just the attributes of the current group of HIV-patients in Ukraine.

The study has several limitations. The most important of them is related to small number of study participants, which makes establishing associations more difficult. Additionally, because of late HIV diagnosis some of the risk factor data and other measurements were missing for a substantial part of the group. Due to challenging laboratory diagnostics we were not always sure regarding a particular species causing the fungal infection, so we have to relate our findings to yeast fungal infections in general.

\section{Conflict of interest}

The authors declare no potential conflicts of interest with respect to the research, authorship, and/or publication of this article.

\section{References}

1. Cox JA, Lukande RL, Lucas S, et al. Autopsy causes of death in HIVpositive individuals in sub-Saharan Africa and correlation with clinical diagnoses. AIDS Rev 2010; 12: 183-194.

2. Birbeck GL. HIV neurology in the developing world. In: Handbook of Clinical Neurology. Elsevier, 2007; p. 33-43.

3. Collazos J. Opportunistic infections of the CNS in patients with AIDS: diagnosis and management. CNS Drugs 2003; 17: 869-887.

4. Portegies P, Berger JR. Introduction to HIV infection and neuroAIDS. In: Handbook of Clinical Neurology. Elsevier, 2007; p. 1-2.

5. Mamidi A, DeSimone JA, Pomerantz RJ. Central nervous system infections in individuals with HIV-1 infection. J Neurovirol 2002; 8: 158-167.

6. Sacktor N. The epidemiology of human immunodeficiency virusassociated neurological disease in the era of highly active antiretroviral therapy. J Neurovirol 2002; 8 Suppl 2: 115-121.

7. Tan IL, Smith BR, von Geldern G, et al. HIV-associated opportunistic infections of the CNS. Lancet Neurol 2012; 11: 605-617.

8. Bolokadze N, Gabunia P, Ezugbaia M, et al. Neurological complications in patients with HIV/AIDS. Georgian Med News 2008; 165: 34-38.

9. Hakim JG, Gangaidzo IT, Heyderman RS, et al. Impact of HIV infection on meningitis in Harare, Zimbabwe: a prospective study of 406 predominantly adult patients. AIDS 2000; 14: 1401-1407. 
10. Marukutira T, Huprikar S, Azie N, et al. Clinical characteristics and outcomes in $303 \mathrm{HIV}$-infected patients with invasive fungal infections: data from the Prospective Antifungal Therapy Alliance registry, a multicenter, observational study. HIV AIDS (Auckl) 2014; 6: 39-47.

11. Sharma RR. Fungal infections of the nervous system: current perspective and controversies in management. Int J Surg 2010; 8: 591-601.

12. Rauchway AC, Husain S, Selhorst JB. Neurologic presentations of fungal infections. Neurol Clin 2010; 28: 293-309.

13. Uppin MS, Anuradha SV, Uppin SG, et al. Fungal infections as a contributing cause of death: an autopsy study. Indian J Pathol Microbiol 2011; 54: 344-349.

14. Richardson M, Lass-Florl C. Changing epidemiology of systemic fungal infections. Clin Microbiol Infect 2008; 14 Suppl 4: 5-24.

15. Sims CR, Ostrosky-Zeichner L, Rex JH. Invasive candidiasis in immunocompromised hospitalized patients. Arch Med Res 2005; 36 : 660-671.

16. Tauber SC, Eiffert H, Kellner S, et al. Fungal encephalitis in human autopsy cases is associated with extensive neuronal damage but only minimal repair. Neuropathol Appl Neurobiol 2014; 40: 610-627.

17. Henao NA, Vagner B. Infections of the central nervous system by Candida. Journal of Infectious Diseases and Immunity 2011; 3: 79-84

18. Murray CJ, Ortblad KF, Guinovart C, et al. Global, regional, and national incidence and mortality for HIV, tuberculosis, and malaria during 1990-2013: a systematic analysis for the Global Burden of Disease Study 2013. Lancet 2014; 384: 1005-1070.

19. DeHovitz J, Uuskula A, El-Bassel N. The HIV epidemic in Eastern Europe and Central Asia. Curr HIV/AIDS Rep 2014; 11: 168-176.

20. Pappas PG, Kauffman CA, Andes DR, et al. Clinical Practice Guideline for the Management of Candidiasis: 2016 Update by the Infectious Diseases Society of America. Clinical Infectious Diseases: An Official Publication of the Infectious Diseases Society of America 2016; 62: e1-e50.

21. Moran CA, Terry Ch, Nguyen ML, et al. Use of Cerebrospinal Fluid $(1,3)-\beta$-D-Glucan to Monitor Treatment Response in Candida albicans Meningitis in an HIV-infected Patient. Infectious Diseases in Clinical Practice 2018; 26: e70-e72.

22. Ellepola AN, Morrison CJ. Laboratory diagnosis of invasive candidiasis. J Microbiol 2005; 43: 65-84.

23. Jones JM. Laboratory diagnosis of invasive candidiasis. Clin Microbiol Rev 1990; 3: 32-45.

24. Sacktor N, Nakasujja N, Skolasky RL, et al. Benefits and risks of stavudine therapy for HIV-associated neurologic complications in Uganda. Neurology 2009; 72: 165-170.

25. Wright EJ. Neurological disease: the effects of HIV and antiretroviral therapy and the implications for early antiretroviral therapy initiation. Curr Opin HIV AIDS 2009; 4: 447-452.

26. Yechoor VK, Shandera WX, Rodriguez P, Cate TR. Tuberculous meningitis among adults with and without HIV infection. Experience in an urban public hospital. Arch Intern Med 1996; 156: 1710-1716.

27. Sütlaş PN, Unal A, Forta H, et al. Tuberculous meningitis in adults: review of 61 cases. Infection 2003; 31: 387-391.

28. Lu CH, Chang WN, Chang HW. The prognostic factors of adult tuberculous meningitis. Infection 2001; 29: 299-304.

29. Kelly MJ, Benjamin LA, Cartwright K, et al. Epstein-Barr virus coinfection in cerebrospinal fluid is associated with increased mortality in Malawian adults with bacterial meningitis. J Infect Dis 2012; 205: 106-110.

30. Mavilio D, Benjamin J, Daucher M, et al. Natural killer cells in HIV-1 infection: dichotomous effects of viremia on inhibitory and activating receptors and their functional correlates. Proc Natl Acad Sci U S A 2003; 100: 15011-15016.

31. Mansour I, Doinel C, Rouger P. CD16+ NK cells decrease in all stages of HIV infection through a selective depletion of the CD16+CD8+CD3- subset. AIDS Res Hum Retroviruses 1990; 6: 1451-1457.
32. Tomkinson BE, Wagner DK, Nelson DL, Sullivan JL. Activated lymphocytes during acute Epstein-Barr virus infection. J Immunol 1987; 139: 3802-3807.

33. Zhang Y, Wallace DL, de Lara CM, et al. In vivo kinetics of human natural killer cells: the effects of ageing and acute and chronic viral infection. Immunology 2007; 121: 258-265.

34. Williams H, McAulay K, Macsween KF, et al. The immune response to primary EBV infection: a role for natural killer cells. Br J Haematol 2005; 129: 266-274.

35. Beno DW, Stover AG, Mathews HL. Growth inhibition of Candida albicans hyphae by CD8+ lymphocytes. J Immunol 1995; 154: 5273-5281.

36. Murphy JW, Hidore MR, Wong SC. Direct interactions of human lymphocytes with the yeast-like organism, Cryptococcus neoformans. J Clin Invest 1993; 91: 1553-1566.

37. Levitz SM, Dupont MP, Smail EH. Direct activity of human T lymphocytes and natural killer cells against Cryptococcus neoformans. Infect Immun 1994; 62: 194-202.

38. Huffnagle GB, Lipscomb MF, Lovchik JA, et al. The role of CD4+ and CD8+ $\mathrm{T}$ cells in the protective inflammatory response to a pulmonary cryptococcal infection. J Leukoc Biol 1994; 55: 35-42.

39. Voice RA, Bradley SF, Sangeorzan JA, Kauffman CA. Chronic candidal meningitis: an uncommon manifestation of candidiasis. Clin Infect Dis 1994; 19: 60-66.

40. Edwards JE Jr. Candida species. In: Principles and Practice of Infectious Diseases. Bennett JE, Dolin R, Blaser MJ (eds.). Elsevier - Health Sciences Division, 2014; p. 2879-2894.

41. Vazquez JA, Sobel JD. Candidiasis. In: Essentials of Clinical Mycology. Kauffman AC, et al. (eds.). Springer, New York, 2011; p. 167-206.

42. Sánchez-Portocarrero J, Pérez-Cecilia E, Corral O, et al. The central nervous system and infection by Candida species. Diagn Microbiol Infect Dis 2000; 37: 169-179.

43. Casado JL, Quereda C, Oliva J, et al. Candidal meningitis in HIVinfected patients: analysis of 14 cases. Clin Infect Dis 1997; 25: 673676. 